HSTC Bulletin

Journal of the History of Canadian Science, Technology and Medecine

hstc

Revue d'histoire des sciences, des techniques et de la médecine au Canada

bulletin

\title{
Have Canadians Failed to Innovate? The Brown Thesis Revisited
}

\section{Christian De Bresson}

Volume 6, numéro 1 (20), janvier 1982

URI : https://id.erudit.org/iderudit/800130ar

DOI : https://doi.org/10.7202/800130ar

Aller au sommaire du numéro

Éditeur(s)

HSTC Publications

ISSN

0228-0086 (imprimé)

1918-7742 (numérique)

Découvrir la revue

Citer cet article

De Bresson, C. (1982). Have Canadians Failed to Innovate? The Brown Thesis Revisited. HSTC Bulletin, 6(1), 10-23. https://doi.org/10.7202/800130ar

Copyright (c) Canadian Science and Technology Historical Association / Association pour l'histoire de la science et de la technologie au Canada, 1982
Ce document est protégé par la loi sur le droit d'auteur. L'utilisation des services d'Érudit (y compris la reproduction) est assujettie à sa politique d'utilisation que vous pouvez consulter en ligne.

https://apropos.erudit.org/fr/usagers/politique-dutilisation/ 


\title{
HAVE CANADIANS FAILED TO INNOVATE?
}

\author{
THE BROWN THESIS REVISITED
}

Christian de Bresson*

(Received 28 June 1981. Revised/Accepted 14 January 1982.)

\section{INTRODUCTION}

The common prejudice about innovation in Canada is simple: there is no innovation. Other versions of the myth are: Canadians are conservative and do not have an entrepreneurial drive; capitalist 'animal spirits' do not really function in Canada. All of this implies that the capitalist nerve fails in Canada, and entrepreneurial endeavours are virtually nonexistent.

One of the most influential books promoting this view is J.J. Brown's Ideas in Exile. It rests in numbers in the racks of the main undergraduate university libraries across the country as the only broad empirical source about inventions and innovations in Canada. In it, Brown had the merit to bring a wealth of examples and empirical facts to light. Because of this, some of the conclusions of his book have pervasively influenced journalistic comments, semi-academic work, and even themes of some government policy reports. Glossy presentations, such as the Canadian Inventions Book, echo Brown's ideas. The lack of an alternative analysis had made Ideas in Exile largely contributive in shaping public opinion about technological innovation.

Until an alternative set of facts disproves Ideas in Exile and counteracts its broad influence, it is necessary to expose some of the questionable common public assumptions promoted by J.J. Brown about innovations in Canada. It is our responsibility, as social scientists, to diffuse the findings of this work to the public in order to reveal and undermine prejudices and idiosyncracies. This will help increase pubIic awareness and progressively generate a demand for the right type of research.

The Science Council of Canada has recently uncovered a set of facts which may suggest quite another picture for industrial innovation in Canada. However, until the findings are validated in further work, all the results should be regarded as provisional findings at this time. Whereas 'scientific knowledge is international by nature ... technologies ... reflect fairly fully the differences of level of economic development and in the ways of life adopted by the various societies.'l Furthermore, according to J.D. Bernal's

* New Westminster, B.C. 
definition, technologies are a set of personally acquired procedures of production which cannot be transplanted simply. All production processes require the contribution of a specific 'know-how' that assumes some understanding of natural phenomena and of the means available for mastering them. It is in this way that the link between science and technology is established.

Every society evolves its own technology, embodied in tools and skills. Societies with increasing population and production have had to make choices about investment in machinery and qualifications of manpower. Except in primitive and stagnant economics where investments are only made to replace outworn equipment, without in any, way changing the technology, investment is always accompanied by some measure of technological innovation. 3 . This implies, contrary to J.J. Brown, that economic growth and investment in Canada evolves and generates its own innovation. Canada, as a growing society, had to make investment choices and has had, perforce, to privately and/or collectively appropriate procedures of production and evolve its technology -- even if only through adaptation.

Where in Canada does one expect the technology to evolve? Wherever domestic demand is supplied by domestic production, one can expect a shift in the demand to motivate corresponding change by the supplier, resulting in new or modified products. Similarly, any price pressures exerted by domestic demand can stimulate the domestic supplier to introduce a production process change or improvement.

Our study also examined all substantial production for export, on the premise that a change of demand abroad will cause Canadian suppliers to institute technological changes. Furthermore, it was assumed that wherever Canada had been involved in production for any amount of time, its assimilation of production processes and procedures led to a growth in either adaptive or innovative know-how. Specific local conditions are bound to generate specific needs but there should only be a random chance that these would generate only previously-established technological responses.

\section{THE INNOVATION PROCESS}

Having delineated our broad field of study, we sought to establish where the increments of technological know-how developed. What were the indicators of technical modification, improvements and establishment of new ways of doing things? One knows very little of the process through which technological change and innovation occur. Studies that tried to discriminate between successful and unsuccessful innovations have been inconclusive. However, it has been established that innovation involves close interaction of economic actors, be it in success or failure. ${ }^{4}$ Once innovation has established an interaction between a set of economic actors, the interaction tends to become interative. 
oligopsomy in British Columbia for logging, sawmilling, pulping equipment, and wood product transportation, began to integrate its different lines of operation on the West coast in the early 1950s. These lines included logs, lumber, newsprint and other wood products. With vast timber leases on the West coast, it wanted to orient the harvested timber either to sawmills, or mechanical or chemical pulp mills to maximize the value of its resource according to needs in production and variations of the market price of newsprint or lumber and board. Mechanization of the harvesting and logging operation, which occurred in the late Forties with the introduction of special tractors -- the fourwheel articulated skidder that brought the cut timber from where it was felled to the first logging road -- and diesel trucking with radio communications, allowed forest-product manufacturing to be removed further away from the harvesting areas. The combination of these developments, along with the fact that the immediate vicinities of waterways had been harvested, led MacMillan-Bloedel to integrate all its production in the lower inland Pacific coast waters.

The key problem was how to transport logs efficiently on the Pacific inland waters. Pushing booms with boom-dozers or pulling them with tugs would lose many logs, impeding navigation. This also resulted in the logs being brought back a second time by beachcombers, often damaged. Boom-bundling was costly and complicated in the bush. If loading logs on to a barge near the harvesting port appeared conceivable, unloading barges near the mills in urban areas was very costly and took too much time. MacMillan-Bloedel approached

Vancouver naval architects who were no longer occupied by war production. They came up with a simple idea. If one could flood the ballasts of barges from one side, the barges would capsize and release their load, saving all the time of unloading.

The naval architects then approached Burrard Dry Docks who had built the first self-dumping barge in the early Fifties. At first, these were pulled by tugs or pushed by boom-dozers. An interaction fertile of innovation was established. The self-dumping barges were then improved to include self-loading cranes. The second generation had emerged: the self-loading, self-dumping barge. Later, in the early Seventies, Yarrows Ship Yard near victoria built self-propelled, self-loading, self-dumping barges. The innovative interaction had become iterative.

There are numerous examples of this sort. All such examples resemble case-specific stories. But they all have commonalities: a user and a supplier got together to solve a specific techno-economic problem. How could one record the occurrences of modification and/or generation of technology and the instances of the accumulation of know-how? To answer this question, we posed another: what are the means of communications between suppliers and users? They include trade and professional journals, trade fair experts that act as gatekeepers, technical societies and meetings, etc. 
Financed by Industry, Trade and Commerce, the writer scanned at the University of British Columbia two main media of communication. First, three hundred experts responded to a survey and/or were interviewed. Secondly, all trade journals relating to industries of involvement in Canada were scanned for a rough description of an innovation, an approximate date of commercial introduction, and the name of a firm believed to have commercialized it. In the fall of 1978, each firm was asked to confirm these facts. The definition of innovation used was Schumpeter's: a commercialized new combination of production means to suit a given need. 5 Either the means or the need or the combination had to be new.

How did this definition enable us to distinguish innovation from incremental improvement in production? All innovation by our definition implied some measure of discontinuity in the production process. For example:

- the Foudrinier paper-making machine had to be replaced by the twin wire paper-making machine (Papriformer) of Dominion Engineering in Abitibi paper plant (major innovation); or

- the Foudrinier machine had to be rebuilt with a new felt to increase its speed (minor improvement innovation); or

- during the down-time of the machine, it had to be fitted with a quality control instrument to measure the humidity or the glaze of the paper (accessory innovation).

But in all cases, innovation involved discontinuity in the production process. As schumpeter points out, it involves. replacing one production function relating a set of factors (or ingredients of production) to the output (product) by another production function. The description of the innovation not only involves giving the description of the ingredients and their relative proportion (the starting point of a recipe) ${ }^{6}$ but also some description of the order and nature of the 'cooking' operations of the ingredients. If one fails to look into the order and nature of the operation, one rarely captures technical change. By describing this discontinuity in the order and nature of operations, we attempted to capture it.

A Canadian innovation was defined as the first production of a product in Canada or the first use of a process in Canada for the purposes of commercial production. The borderlines of the field were not discrete. For example, harvesting machinery made in Scandinavia for first use in Canada qualified as a 'Canadian innovation' according to our definition, alongside the first comnercial use in the world of heavy water nuclear power generation (an imported scientific knowhow). Even the production, in Canada, of a piece of machinery only used abroad qualified as a 'Canadian innovation.'

In addition, we did not assume any discontinuity between the 
adaptation of foreign technology, incremental change and major innovation. often, interaction between two industries, at the beginning, only breeds incremental changes for adaptation. In this way, know-how is accumulated enabling the initiation of major technological changes. This reasoning led us to expect that at least incremental technological change of an adaptive nature compounded, would lead to some major innovations. Our data will be available to all researchers.

\section{J.J. BROWN'S THESIS}

Brown's ideas may be summed up in the following quote:

I have collected many examples of inventions where we had a genuine world first. In some cases we had a commanding head-start on the rest of the world, amounting to as much as twenty years, yet we never have been able to make one of these headstarts, presented to us as a gift by some dedicated individual, pay off for us in terms of world prestige and dollars. Time after time, we have gotten there first after a magnificent sprint, and then stood idly around for years waiting to collect the risk capital required to get the industry going. Usually by the time we have solved the financial problem, other less torpid nations have caught up with us and passed us. This happened with the variable pitch propeller, with the jet-liner, with the automatically controlled machine tool, with the electric organ....?

If Brown were to remain coherent with his main statement that Canadian inventions go abroad to be developed into fullfledged commercial innovations, he should have checked the proportion of Canadian inventions that go abroad. Then, to further contend that Canada lacks development nerve, Brown should also have checked foreign inventions developed commercially in Canada.

Plutonium production with heavy water, for example, was developed in Canada with British, Scandinavian and French knowhow -- not with a Canadian invention -- although once the process got started, some was forthcoming. Synthetic rubbermaking through the Bromo-Butyl process was a Canadian first of Polymer Corporation (now Polysar), but the technology was not Canadian at the inception. Pratt and Whitney's PT6 engine was an innovation with considerable impact on the size of planes but, again, the technology was not Canadian.

All the above are obvious cases of commercially viable technological developments which brought massive business to Canada and allowed Canada to build up technological know-how; but for these, Canada, as is to be expected, was dependent on a foreign technological service which Brown did not consider in his research. These examples are enough to indicate that Canada is involved in entrepreneurial activity. 
Brown further states, 'The paradox that enlivens the history of Canadian invention is that Canada is a great producer of ideas yet has no native technical industries.' By 'native industries' Brown may be referring to industries which developed based exclusively on domestic science and technology. But very few industries develop in this way. There is always some measure of adaptation involved in the innovation process. As a sample of this, we chose Canadian inventions referred to in Chapters 12 and 13 of Ideas in Exile covering the post-war period to the mid-1960s. A selection of twenty of these of known date will suffice to illustrate the point. We have added in parentheses next to each invention either ' $S$ ' for commercialized or ' $E$ ' for not commercialized yet or 'exiled. 18 Even a cursory examination of the inventions tends to give us a different picture. Canadian successes in technology seem to emerge in the traditional areas of strength of the Canadian economy: the recovery of high value per volume goods ('staples'), their transport over large distance, with the corresponding development of specialized high speed transportation crafts (airplanes, boats, off-road vehicles), the tapping and transmission of energy over long distances, etc.

Jacob Schmookler, in Invention and Economic Growth, showed that if one classified patents by using industry, one would find a relationship between the rate of patent registry and the economic growth of an industry.9 This does not imply, however, that the registered inventive activity of a specific nationality correlates with the industry's growth in that same country. Hence, there is no a priori reason why native Canadian innovations should stem from indigenous inventions. of course, snowmobile inventions are to be expected in snowy countries and will most likely be developed into innovations in those countries. However, the key invention of the rubber tread which enabled the Bombardier snowmobile to become reliable was a product applicable to many conveyor technologies world wide. But Brown implies that local invention should be developed locally.

\section{DO FIRMS PREFER DOMESTICALLY-GROWN TECHNOLOGY?}

Technical know-how in Canada is bound to facilitate the assimilation of international knowledge just as much as to promote domestic production of knowledge. No solution of continuity exists between assimilation, adaptation and invention. It is expected that a large share of technological developments in Canada be made with imported ideas, if only because Canadian needs will be met with ideas taken from the international stock of inventions to which Canada contributed a share.

J.J. Brown's journalistic work was based on a false assumption that the conditions that preside over the inventive activity also determine the innovative activity and that Canadian firms should give preference to Canadian-grown inventions. It is these assumptions which blur the lines between proprietary and non-proprietary technical knowledge and often discard the second. Temporary monopoly in the 
application of knowledge is important to a firm initiating change. The trade secret is the best means of securing this. A set of patents is the second best means; and an exclusive licence the third best means. But firms have little reason to prefer domestic inventions to foreign ones. A national community may do so but this has not been the orientation of the Canadian government's policy.

The contemporary and growing need of firms to perform their own research and development stems from the concern about know-how monopoly. The best way of being able to cash in on research findings made in research establishments before they become public -- and unusable for business -- is to perform some measure of basic research in-house. In-house research tunes in the firm to on-going, promising research and enables the acquisition of proprietary rights early enough in time.

Moreover, all societies generate technologies that tend to fully reflect their own level of development and their own way of doing things. Because technologies are privately and individually assimilated means of producing, they reflect the specificities of socio-economic development. An inquiry into technological innovation in Canada, therefore, should not proceed from the image of what innovation should be, according to a foreign model, but rather what innovation is in relation to specific production processes in Canada. It is our contention that Brown started with a US model in mind, projected it onto canada and, as expected, found it did not fit. But why should Canada innovate in the same streams as our southern neighbour?

Our own data on Canadian innovations from 1947 to 1976 indicates technological development in the following areas: power generating equipment and power transmission systems; radio, radar and telecommunications; logging and pulping; mining, milling and smelting; surveying and mapping; scientific, medical, control instrumental and avionics; sorting, material handling, packaging and transportation systems; special purpose transport equipment.

\section{USER ORIENTATION OF TECHNOLOGICAL PRODUCTION}

The user 'pull' and demand of existing economic activity is very often more important in orienting technological change than domestically available inventions. User demand enables us, in large measure, to explain successes. If Its absence throws light on the underlying causes of failure. Consider Brown's 'exiled' invention, the automatically-controlled machine tool. There is very little mass production of manufactured goods in Canada; little machinery is thus manufactured to answer the needs of such production. Machinery and equipment making in Canada are often custom oriented, a oneshot affair. The prerequisite standardization of production operations required for numerically controlled machine tools does not exist. 
Nor is Canada prone to the mass production of consumer goods such as zippers. Another example of a mass consumer goods, invented and 'exiled,' is the 'electric kettle.' The reasons inventions are exiled often seem due to the lack of pull in Canada and existing demand elsewhere. However, Montreal is the world centre for panty hose. Therefore, it is difficult to generalize.

The exceptions are also illustrative of the user orientation of technical change. Bombardier is one of the rare manufacturers in Canada to have evolved performance vehicles into a dominant engineering design for standardized production: the snowmobile. It achieved this in a domain where a US manufacturer had previously failed. Off-road vehicles, packaging machinery and mass production of standardized homes are exceptional areas for innovation. All of these areas benefit in Canada from conditions which are more favourable than in the USA, thus creating a demand pull for the technologies.

\section{BROWN'S DEFICIENT CONCEPTS}

Brown's errors are essentially methodological. He defines innovation and invention in a way as to lose their distinction. He states, 'an "invention" is an idea embodied into a piece of physical equipment which provides some goods or service we did not have before. An "innovation" is all the above except it does hot have to be embodied in any physical equipment. 12 schumpeter's definition of innovation would have been more appropriate as an object of his study as it clearly distinguishes between a non-commercialized invention and a commercialized one.

He then goes on to define a 'Canadian invention' in a debatable way: "My working definition of a "Canadian invention" is that either the inventor was educated here or the basic concept for this invention came to him while he was living in Canada. 13 This definition has shortcomings. Since scientific knowledge has been organized internationally, interactions between researchers over national boundaries appear to be more, or at least as important as, nationality. linguistic groups are more crucial to communication of ideas than citizenship. Moreover, inventors always have a higherthan-normal percentage of immigrants.

Using Brown's definition, Bell's telephone becomes 'Canadian.' From the same standpoint, heavy water plutonium production should be British, but Brown classifies it under 'Canadian' innovations. He includes many foreign inventions commercially developed in Canada when it suits him. Even if he had limited himself to trade journals and interviews of key people (which he did) rather than for commercialized infentions, he would have come up with the list similar to ours 14 : 240 items amongst 4,100 items for which there are at least two different information sources (a trade journal, an expert, two experts, etc.). For comparable periods 1945-1965, Brown's and our data have comparable items, some being identical; but if one excludes his 'exiled inventions,' his list 
is much shorter. In other words, while his own data does not verify his case, neither would a more systematic analysis with the same sources have done so.

\section{A FEW FACTS THAT CONTEST BROWN'S IDEAS}

A few sets of facts that companies have confirmed to the Science Council which contest J.J. Brown's contention are: in certain industries

(i) Canadian firms claim numerous 'world firsts;'

(ii) Canadian firms claim an even more surprising ratio of world seconds amongst the total of the technological changes adopted from abroad;

(iii) Small firms in Canada perform, as in other countries, a large share of the innovations in many industries.

'World firsts' are innovations for which the manufacturer knows of no precedent in the world. These comprise approximately 408 of the total innovations. However, given that firms may be biased, the facts still require cross-checking with another source. Among these world firsts, there are also innovations which were not resounding commercial successes, second generation improvement of foreign innovations, innovations of secondary commercial importance, others of secondary technical impact, as well as those of genuine world importance. The innovations still have to be graded and $e-$. valuated and the degree of commercial success of each innovation has yet to be established. But one thing is immediately apparent: there is no lack of contention by Canadian firms of being 'world firsts,' which is a sign of the existence of entrepreneurial endeavours in Canada. Roughly half of these Canadian world firsts were developed in-house; probably a higher proportion yet, were developed in Canada. This evidence of world firsts is enough to weaken Brown's contention that Canadians are inventors but not innovators and hence ideas go into exile.

Secondly, almost as interesting is the data relating to the lag in adoption of foreign technology. Contrary to common belief, there is very little economic advantage of being the first to pioneer an innovation over being an early adopter. The entrepreneurial profit comes at the beginning of the diffusion curve before 508 of the production is done with a new process. This, then, comes to determine the mean production price in the industry after the initial debugging of a process.

Technologically, the early part of the learning curve is the most propitious for acquiring technological know-how. It is at this stage when the major cost-saving improvements and modifications which stabilize a process or a product design into a standard form, are introduced. The very early $R$ \& $D$ endeavours not only have little economic benefits but have little technological learning benefits.

The approach of the Japanese is instructive in this respect. They systematically screen all new but established products 
and inventions and choose the most promising to import in an unbundled form (machines, products, materials, technologists, engineers, and professors). In this way, they collectively acquire and assimilate the knowledge and know-how related to that technology. This practice is based on the understanding that one gains more from adopting, adapting and learning early from foreign technology than from duplicating original path breaking $R \& D$ work.

Similarly, Canada's reliance on foreign technology was consciously cultivated in the past. Canadian government policy on industrialization was based on attracting technology from a more advanced area rather than indigenous technological development.15 This model is consistent with our claim that Canada is an early adopter. But a startling fact revealed by our data is that when we adopt foreign technology, we are often the second in the world in many areas. What is the validity of our data? Perhaps firms report more when they are second and less when they are third or fourth.

The examination of our data shows, however, that the industries in which we are world seconds are areas of relative strength: non-ferrous metal smelting, iron and steel, pulping, some industrial chemicals, etc. Furthermore, we are seconds with foreign subsidiaries, Canadian multinationals and independents. There appears to be a consistent behaviour.

Raymond Vernon's research group on multinationals at Harvard University Business School has recently released the preliminary results of a study started in 1974 that indicates similar results. 16 He examined fifty-seven us multinationals and looked at 400 of their innovations and 400 imitations and traced the story of the establishment of the product lines around the world in their subsidiaries. Canada was more often than not the second in the world to get a product line. This is in agreement with our findings.

Since the experience of the first plant enables one to identify many of the cost saving possibilities, being second could procure for Canada an economic and learning advantage. For example, DuPont Canada established the second plant for an important intermediate nylon. Then, in order to bring down the US production plans to Canadian scale they introduced two innovations that have subsequently been used in all plants the world over; one of these is a major new catalyst they will not talk about even in patents.

Aside from multinationals, the adoption of the oxygen steelmaking process by Dofasco in the late Fifties after the Austrians had established the process, is another case in point. Early adoption is the adoption at the most beneficial moment in the life cycle of a technology from the point of view of economics and the learning curve.

The data only allows us to pose the question: does Canada possess this potential advantage in certain areas? In order to determine the significance of being second in the world to adopt an innovation, we would need to qualify our data with 
information on the lagtime between first commercialization of the innovation elsewhere and first adoption in Canada. However, lagtimes are variable and depend on the industry, business cycle, etc. But what is certain is that the set of facts we uncovered militate against Brown's thesis. If Canada lacked entrepreneurial and innovative nerve, then one would expect Canada to adopt foreign innovation promptly in any areas. The fact that Canada does, at least in certain industries such as steel and smelting, makes this thesis highly unlikely.

Finally, we have found that small entrepreneurs in industries such as instruments, machinery, specialized transport equipment, logging, and electronics contribute a heavy proportion of the innovations as in other western free market countries (see Table). In other words, the 'animal spirits' of capitalist free enterprise culture seem to be breeding quite well in the Canadian environment. If Brown's thesis about entrepreneurial and innovative failure were true, one should not expect the small operator-owned enterprise to be involved in innovation.

TABLE

PERCENTAGE OF INNOVATIONS IN EACH INDUSTRY BY SIZE OF FIRM17

\begin{tabular}{|c|c|c|c|c|c|c|}
\hline Number & Industry & $1-19$ & $\begin{array}{l}\text { Enployme } \\
20-199\end{array}$ & $\begin{array}{r}\text { ent Size } \\
200-499\end{array}$ & $\begin{array}{l}\text { (\# of Empl } \\
500-999\end{array}$ & $\begin{array}{l}\text { oyees) } \\
1000\end{array}$ \\
\hline 165 & $\begin{array}{l}\text { Plastics fabricating } \\
\text { industries }\end{array}$ & 8.3 & 66.7 & 25.0 & 0.0 & 0.0 \\
\hline 251 & $\begin{array}{l}\text { Saw mills, planing } \\
\text { mills \& shingle mills }\end{array}$ & 0.0 & 9.5 & 0.0 & 0.0 & 0.0 \\
\hline 271 & Pulp \& paper mills & 5.3 & 31.6 & 17.5 & 3.5 & 42.1 \\
\hline 291 & Iron \& steel mills & 0.0 & 5.6 & 0.0 & 0.0 & 88.9 \\
\hline 295 & Smelting \& refining & 5.6 & 22.2 & 11.1 & 16.7 & 38.9 \\
\hline 308 & Machine shops & 14.3 & 85.7 & 0.0 & 0.0 & 0.0 \\
\hline 315 & Machinery \& equipment & 14.5 & 36.4 & 27.3 & 18.2 & 1.8 \\
\hline 321 & $\begin{array}{l}\text { Aircraft \& aircraft } \\
\text { parts manufacturers }\end{array}$ & 1.2 & 4.9 & 3.7 & 28.4 & 61.7 \\
\hline 373 & $\begin{array}{l}\text { Manufacturers of plas- } \\
\text { tics \& synthetic resins }\end{array}$ & 0.0 & 50.0 & 8.3 & 0.0 & 41.7 \\
\hline 378 & $\begin{array}{l}\text { Manufacturers of indus- } \\
\text { trial chemicals }\end{array}$ & -6.3 & 37.5 & 18.8 & 6.3 & 31.3 \\
\hline 3782 & $\begin{array}{l}\text { Industrial chemicals } \\
\text { (inorganic) }\end{array}$ & 1.5 & 0.0 & 1.5 & 10.6 & 83.3 \\
\hline 3783 & $\begin{array}{l}\text { Industrial chemicals } \\
\text { (organic) }\end{array}$ & 0.0 & 53.3 & 33.3 & 0.0 & 13.3 \\
\hline 391 & $\begin{array}{l}\text { Scientific \& profes- } \\
\text { sional equipment } \\
\text { industries }\end{array}$ & 25.0 & 65.0 & 5.0 & 0.0 & 5.0 \\
\hline
\end{tabular}


A more probable feature of innovation in Canada suggested by our survey is its customs orientation. Innovative small firms seem to have difficulty in making the transition from producing for a client to producing for a market. Cases of such transitions are rare: the snowmobile, the four-wheel articulated skidder, the chip'n saw, the factory-built mobile home, etc. The problem in Canada would not be so much the lack of entrepreneurial nerve as the barriers to entry and industrial growth. It is not so much the lack of small innovative firms but that of survival and growth of mediumsized ones.

\section{CONCLUSION}

Before studying the specific features for innovation in Canada, it is necessary to know simply what innovation exists. We have found from our research that technological innovation exists in Canada and is pervasive. However, in order to examine the scope of failure, we must establish. What the successes are and where the innovative potential lies. This is what we have started to do at the Science Council.

\section{Acknowledgements}

The author wishes to acknowledge the assistance of Isme Alam in obtaining the empirical data and the Science Council of Canada for financial support.

\section{NOTES}

1. P. Piganiol, 'Some International Aspects of Technological Innovation,' UNESCO SC/Conf. 4:10 (1970), 1.

2. J.D. Bernal, The Social Function of Science (Boston, 1967).

3. Christian De Bresson, 'Technology Transfer in Three Mediterranean Countries: An Empirical Analysis,' Mondes en Developpement 15 (1976), 493-521.

4. N.R. Baker et al., 'The Relationship Between Certain Characteristics of Industrial Research Projects and their subsequent Disposition, IEEE Transactions on Engineering Management (Nov. 1971). See, also, R. Rothwell et al., 'SAPPHO Updated: Project SAPPHO Phase II,' Research Policy (Nov. 1974).

5. Joseph Schumpeter, Business Cycles: A Theoretical, Historical and Statistical Analysis of the capitalist Process (New York, 1939).

6. This is what one calls the technical co-efficients of a process in input-output economics.

7. J.J. Brown, Ideas in Exile (Toronto, 1967), 342.

8. A selection of innovations from 1946 to 1965 (one per yearl follows: 
1946: Orenda engines for small aircraft and standby power plants (S);

1948: Digital recorder for measuring speed of paper webs (Electronic Associates) (S);

1949: Avon jetliner (E);

1950: Oxygen process in steel making (Dofasco) (S);

1951: Cobalt 60 cancer therapy units (AECL) (S);

1952: Aluminum-sheathed high voltage oil-filled cable (Canada wire and Cable) (S);

1954: Oil well pump driven by natural gas pressure (James Green) (E) ;

1955: Improved C-frame betameter for measuring weight of paper-continuous scanner (Isotope Products) (S);

1957: Drag dredge cables for 10,000 HP A/C motors at $13 \mathrm{KV}$ (Northern Electric) (S):

1958: AVRO Arrow supersonic interceptor (E);

1959: High intensity wet magnetic hematite iron ore separator (Jones) (E) :

1960: Cement block making machine--180 blocks/hr (Facemaster Ltd) (E);

1961: Computer booking of aircraft -- first real-time system (Air Canada) (S);

1962: Jarlan breakwater (S);

1963: STOL Caribou with GE turbo prop (S);

1964: Filtering of wastes through limestone (Chemcell) (E);

1965: Complete integrated automatic control of paper quality (Isotope Products) (S).

9. This finding does not apply to all industries. Joe Townsend of SPRU (Sussex) has shown that in chemicals, abstracts and patents precede fixed investment. See Christopher Freeman, 'The Determinants of Innovation, Market Demand, Technology and the Response to Social Problems,' Futures 11:3 (June 1979), 206-15.

10. See note 13 , below.

11. Davia Mowery and Nathan Rosenberg, 'The Influence of Market Demand upon Innovation: a Critical Review of Some Recent Empirical Studies,' Research Policy 8:2 (April 1979), 102-53. The authors highlight the limitation of the demand-induced explanation of technological change.

12. Brown, op. cit., 3 .

13. Ibid., 4.

14. The following represent a selection of innovations from the Canadian Innovation Data Base representing innovations from 1947-1976 with two different sources confirming the information:

1947: Manufacture of anhydrous magnesium chloride from brucitic limestone;

1948: Dunbar chipper; 
1949: Atomized suspension semi-chemical recovery technique for pulp bleaching;

1950: Synthetic rubber with 35-458 low cost oil/ polymer;

1951: Ear defenders;

1952: Monosodium glutamate;

1953: Articulated wheel vehicle ('skidder');

1954: Self-dumping barge;

1955: Acrylic enamels for appliances and cars;

1956: Tank-type aluminum hopper cars;

1957: Analog flight simulator;

1958: Cobalt-60 irradiators;

1959: Polyurethane sewer pipe joint;

1960: Natural uranium for reactors;

1961: Synthetic plastic patching of plywood;

1962: Jet piercing machine for thermal drilling in open pit mining;

1963: Snowmobile;

1964: Double arbor edger;

1965: Telemetry for Alouette I, II, Explorer XX, Pegasus;

1966: Polyester tire cord for tire use;

1967: Digital flight simulator;

1968: Turbo train;

1969: Avian 2-180 Gyroplane;

1970: Centurion coin telephone;

1971: Downed aircraft distress beacon locator;

1972: Directive antennae for microwave;

1973: C-1 EAX electronic automatic exchange and switching system;

1974: DHC-7 STOL aircraft;

1975: Pulsed chemical laser;

1976: Oxygen bleaching.

15. See Tom Naylor. The History of Canadian Business, 18671914: Industrial Development (Toronto, 1975), Vol. 2. A study of more recent history, Herschel Hardin, A Nation Unaware: The Canadian Economic Culture (Vancouver, 1974), emphasizes the role of Crown corporations.

16. Raymond Vernon and W.H. Davidson, 'Foreign Production of Technology-Intensive Products by U.S. Based Multinational Enterprises,' Harvard Business School, Division of Research, Working Paper HBS 79-5.

17. In this table, we have excluded all industries for which we did not have enough data and data which were highly skewed. The presence of small firms does not seem to warrant a hypothesis of lack of entrepreneurship. Although this data confirms our hypothesis, it is not representative of small and large firms to the contribution of employment in each industry at the present time. once we have completed this, it will be possible for us to assess the importance of small and large firms in each industry. The emergence of a distribution pattern of innovation between small and large firms which exists in most industrialized countries, leads us to believe that there is no major difference in entrepreneurship between Canada and other industrialized countries. 